\title{
VIII. Short account of travels between the tropics, by Messrs. Humboldt and Bonpland, in 1799, 1800, $1801,1802,1803$, and 1804
}

\section{J.C. Delametherie}

To cite this article: J.C. Delametherie (1805) VIII. Short account of travels between the tropics, by Messrs. Humboldt and Bonpland, in 1799, 1800, 1801, 1802, 1803, and 1804, Philosophical Magazine Series 1, 22:85, 54-61, DOI: 10.1080/14786440508676744

To link to this article: http://dx.doi.org/10.1080/14786440508676744

曲 Published online: 18 May 2009.

Submit your article to this journal $₫$

ЏII Article views: 2

Q View related articles $₫$ 
VIII. Shart Account of Travels between the Tropics, by Messrs. Humboldt and Bonpland, in 1799, 1800, 1801, 1802, 1803, and 1804. By J. C. DelameTHERIE.

[Concluded from p. 362.]

Duning his residence at Quito M. Humboldt received a letter from the French National Institute, informing him that captain Baudin had set out for New Holland, pursuing. an easterly course by the Cape of Good Hope. He found it necessary therefore to give up all idea of joining him, though our travellers had entertained this hope for thirteen months, by which means they lost the advantage of an easy passage from the Havannah to Mexico and the Philippines. It had made them travel by sea and by land more than a thousand leagues to the south, exposed to cvery extreme of temperature, from summits covered with perperual snow to the bottom of those profound ravines where the thermometer stands night and day between $25^{\circ}$ and $31^{\circ}$ of Reaumur. But, accustomed to disappointments of every kind, they readily consoled themselves on account of their fate. They were once more sensible that man must depend only on what can be produced by his own energy; and Baudin's voyage, or rather the false intelligence of the direction he had taken, made them traverse immense countries towards which no naturalist perhaps would otherwise have turned his researches. M. Humboldt being then resolved to pursue his own expedition, proceeded from Quito towards the river Amazon and Lima, with a view of making the important observation of the transit of Mercury over the sun's disk.

Our travellers first visited the ruins of Lactacunga, Hambato, and Riobamba, a district convulsed by the dreadful earthquake of the year 1797. They passed through the snows of Assonay to Cuenca, and thence with great difficulty, on account of the carriage of their instruments and packages of plants, by the paramo of Saraguro to Loxa. It was here, in the forests of Gonzanama and Malacatcs, that they studied the valuable tree which first made known to man the febrifuge qualities of cinchona. The extent of the territory which their travels embraced, gave them an advantagre never before enjoyed by any botanist, namely, that of comparing the different kinds of cinchona of Santa Fé, Popayan, Cuenca, Loxa, and Jaen, with the cuspa and cuspare of Cumana and Rio Carony, the latter of which, named improperly Cortex angusiura, appears to belong 
belong to a new genus of the pentandria monogynia, with alternate leaves.

From Loxa they entered Peru by Ayavaca and Gouncabamba, traversing the high summit of the Andes, to proceed to the river Amazon. They had to pass thirty-five times in the course of two days the river Chamaya, sometimes on a raft, and sometimes by fording. They saw the superb remains of the causeway of Ynga, which may be compared to the most beautiful causeways in France and Spain, and which proceeds on the porphyritic ridge of the Andes, from Cusco to Assonay, and is furnished with tambo (inns) and public fountains. They then embarked on a ratt of ochroma, at the small Indian village of Chamaya, and descended by the river of the same name, to that of the Amazons, determining by the culmination of several stars, and by the difference of time, the astronomical position of that confluence.

La Condamine, when he returned from Quito to Para and to France, embarked on the river Amazon only below Quebrada de Chucunga; he therefore observed the longitude only at the moutb of the Rio Napo. M. Humboldt endeavoured to supply this deficiency in the beautiful chart of the French astronomer, navigating the river Amazon as far as the cataracts of Rentema, and forming at Tomependa, the capital of the province of Jaen de Bracamorros, a detailed plan of that unknown part of the Upper Maranon, both from his own observations and the information obtained from Indian travellers. M. Bonpland in the mean time made an interesting excursion to the forests around the town of Jaen, where he discovered new species of cinchona; and after grcatly suffering from the scorching heat of these solitary districts, and admiring a vegetation rich in new species of Jacquinia, Godoya, Porteria, Bougainvillea, Colletia, and Pisonia, our three travellers crossed for the fifth time the cordillera of the Andes by Montan, in order to return to Peru.

They fixed the point where Borda's compass indicated the zero of the magnetic inclination, though at 7 degrees of south latitude. They examined the mines of Hualguayoc, where native silver is found in large masses at the height of eooo toises above the level of the sea, in mines, some metalliferous veins of which contain petrified shells, and which, with those of Huantajayo, are at present the richest of Peru. From Caxamaria, celebrated by its thermal waters, and by the ruins of the palace of Atabualpa, they descended to Truxillo, in the neighbourhood of which are 
found vestiges of the immense Peruvian city of Mansiche, ornamented with pyramids, in one of which was discovered, in the eighteenth century, hammered gold to the value of more than 150,000 l. sterling.

On this western declivity of the Andes our travellers enjoyed, for the first time, the striking view of the Pacific Ocean ; and from that long and narrow valley, the inhabitants of which are unacquainted with rain or thunder, and where, under a happy climate, the most absolute power, and that most dangerous to man, theocracy itself, seems to imitate the bencficence of nature.

From Truxillo they followed the dry coasts of the South Sea, formerly watered and rendered fertile by the canals of the Ynga; nothing of which remains but melancholy ruins. When they arrived, by Santa and Guarmey, at Lima, they remained some months in that interesting capital of Peru, the inhabitants of which are distinguished by the vivacity of their genius and the liberality of their sentiments. M. Humboldt had the happiness of observing, in a pretty complete manner, at the port of Callao at Lima, the end of the transit of Mercury : a circumstance the more fortunate, as the thick fog which prevails at that season often prevents the sun's disk from being seen for twenty days. He was astonished to find in Peru, at so immense a distance from Europe, the newest literary productions in chemistry, mathematics, and physiology; and he admired the great intellectual activity of a people whom the Europeans accuse of indolence and luxury.

In the month of January 1803 our travellers embarked in the king's corvette La Castora for Guyaquil; a passage which is performed, by the help of the winds and the currents, in three or four days, whereas the return from Guyaquil requires as many months. In the former port, situated on the banks of an immense river, the vegetation of which in palms, phumeria, tabernamontuna, and scitaminea, is majestic beyond all description. They heard growling every moment the volcano of Catopaxi, which made a dreadiul explosion on the 6th of January 1803.

They immediately set out that they might have a nearer view of its ravages, and to visit it a second time; but the unexpected news of the sudden departure of the Atlanta frigate, and the fear of not finding another opportunity for several months, obliged them to return, after being tormented for seven days by the mosquitoes of Babaoyo and Ugibar.

They had a favourable navigation of thirty days on the

Pacific 
Pacific Ocean to Acapulco, the western port of the kingdom of New Spain, celebrated by the beauty of its bason, which appears to have been cut out in the granite rocks by the violence of earthquakes; celebrated also by the wretchedness of its inhabitants, who see there millions of piastres embarked for the Philippines and China; and unfortunately celebrated by a climate as scorching as mortal.

M. Humboldt intended at first to stay only a few months in Mexico, and to hasten his return to Europe; his travels had already been too long; the instruments, and particularly the time-keepers, began to be gradually deranged; and all the efforts he had made to get new ones had proved fruitless. Besides, the progress of the sciences in Europe $s$ so rapid, that in travels of more than faur years a traveller may see certain phænomena under points of view which are no longer interesting when his labours are presented to the public.

M. Humboldt flattered himself with the hope of being in England in the months of August or September 1803; but the attraction of a country so beautiful and so variegated as the kingdom of New Spain, the great hospitality of its inhabitants, and the dread of the yellow fever at Vera Cruz, which cuts off almost all those who between the months of June and October come down from the mountains, indnced him to defer his departure till the middle of winter. After having occupied bis attention with plants, the state of the air, the hourly variations of the barometer, the pbrnomena of the magnet, and in particular the longitude of Acapulco," a port in which two able astronomers, Messrs. Espinosa and Galeano, had before made observations, our travellers set out for Mexico. They ascended gradually from the scorching valleys of Mescala and Papagayo, where the thermometer in the shade stood at $32^{\circ}$ of Reaumur, and where they passed the river on the fruit of the crescentia pinnata, bound together by ropes of agave, to the high plateaux of Chilpantzingo, Tehuilotepec and Tasco.

At these heights of six or seven hundred toises above the level of the sea, in consequence of the mildness and coolness of the climate, the oak, cypress, fir, and fern, begin to be seen, together with the kinds of grain cultivated in Europe.

Having spent some time in the mines of Tasco, the oldest and formerly the richest in the kingdom, and having studied the nature of those silvery veins which pass from the hard calcareous rock to micaceous schist and inclose foliaceous gypsum, they ascended, by Cuernaraca and the cold regions 
of Guchilaqua, to the capital of Mexico. This city, which has 150,000 inhabitants, and stands on the site of the old Tenochtitlan, between the lakes of 'Tezcuco and Xochimilo, which have decreased in size since the Spaniards, to lessen the danger of inundations, have opened the mountains of Sincoc, is intersected by broad straight streets. It stands in sight of two snowy mountains, one of which is named Popocatepec; and of a volcano still burning; and, at the height of 1160 toises, enjoys a temperate and agreeable climate: it is surrounded by canals, walks bordered with trees, a multitude of Indian hamlets, and without doubt may be compared to the finest cities of Europe. It is distinguished also by its large scientific establishments, which may vie with several of the old continent, and to which there are none similar in the new.

The botanical garden, directed by that excellent botanist M. Cervantes; the expedition of M. Sesse, who is accompanied by able draftsmen, and whose object is to acquire a knowledge of the plants of Mexico ; the School of Mines, established by the liberality of the corps of miners and by the creative gcnius of M. d'Elhuyar; and the Academy of Painting, Engraving, and Sculpture; all tend to diffuse taste and knowledge in a country the riches of which seem to oppose intellectual culture.

With instruments taken from the excellent collection of the School of Mines, M. Humboldt determined the longitude of Mexico, in which there was an error of nearly two degrees, as has been confirmed by corresponding observations of the satellites made at the Havannah.

After a stay of some months in that capital, our travellers visited the celebrated mines of Moran and Real-del-Monte, where the vein of La Biscayna has given millions of piastres to the counts De Regla ; they examined the obsidian stones of Oyamel, which form strata in the pearl stone and porphyry, and served as knives to the antient Mexicans. The whole of this country, filled with basaltes, amygdaloids, and calcareous and secondary formations, from the large cavern of Danto, traversed by a river to the porphyritic rocks of Actopan, presents phænomena interesting to the geologue, which have been already examined by $\mathbf{M}$. del Rio, the pupil of Werner, and one of the most learned mineralogists of the present day.

On their return from their excursion to Moran in July 1803, they undertook another to the northern part of the kingdom. At first they directed their researches to Huehuetoca, where, at the expense of six millions of piastres, 
an aperture has been formed in the mountain of Sincoc to drain off the waters from the valley of Mexico to the river Montezuma. They then passed Queretaro, by Salamanca and the fertile plains of Yrapuato, to Guanaxuato, a town which contains 50,000 inhabitants: it is situated in a narrow defile, and celebrated by its mines, which are of far greater consequence than those of Potosi.

The mine of count de Valenciana, which has given birth to a considerable town on a hill which thirty years ago scarcely afforded pasture to goats, is already 1840 feet in perpendicular depth. It is the deepest and richest in the world; the annual profit of the proprietors having never been less than three millions of livres, and it sometimes amounts to five or six.

After two months employed in measurements and geological researches, and after having examined the thermal waters of Comagillas, the temperature of which is $11^{\circ}$ of Reaumur higher than those of the Philippine islands, which Sonnerat considers as the hottest in the world, our travellers proceeded through the valley of St. Jago, where they thought they saw in several lakes at the summits of the basaltic mountains so many craters of burnt-out volcanoes, to Valladolid, the capital of the antient kingdom of Michoacan. They thence descended, notwithstanding the continual autumnal rains, by Patzquaro, situated on the margin of a very extensive lake towards the coast of the Pacific Ocean, to the plains of Jorullo, where in the course of one night in 1759 , during one of the greatest convulsions which the globe ever experienced, there issued from the earth a volcano 1494 feet in height, surrounded by more than 2000 mouths still emitting smoke. They descended into the burning crater of the great volcano to the perpendicular depth of 258 feet, jumping over fissures which exhaled flaming sulphurated hydrogen gas. After great danger, arising from the brittleness of the basaltic and sienitic lava, they reached nearly the bottom of the crater, and analysed the air in it, which was found to be surcharged in an extraordinary manner with carbonic acid.

From the kingdom of Michoacan, one of the most agree. able and most fertile countries in the Indies, they returned to Mexico by the high plateau of Tolucca, in which they measured the snowy mountain of the same name, ascending to its highest summit, the peak of Fraide, which rises 2364 toises above the level of the sea : they visited also at Tolucca the famous hand-tree the cheiranthostamon of M. Cervantes, a genus which presents a phanomenon almost unique, 
unique, - that of there being only one individual of it, which has existed since the remotest antiquity.

On their return to the capital of Mexico they remained there several months to arrange their herbals, abundant in gramineous plants, and their geological collections; to calculate their barometric and trigonometrical measurements performed in the cuurse of that year; and in particular to make fair drawings of the geological atlas, which M. Humboldt proposes to publish.

Their return furnished them also with an opportunity of assisting at the erection of the colossal equestrian statue of the king, which one artist, M. Tolsa, overcoming difficulties of which a proper idea cannot be formed in Europe, modelled, cast, and erected on a very high pedestal : it is wrought in the simplest style, and would be an ornament to the finest capitals in Europe.

In January 1804 our travellers left Mexico to explore the eastern declivity of the cordillera of New Spain : they measured geometrically the two volcanoes of Puebla, Popocatepec and Itzaccihuatl. According to a fabulous tradition, Diego Ordaz entered the inaccessible crater of the former suspended by ropes, in order to collect sulphur, which may be found every where in the plains.

M. Humboldt discovered that the volcano of Popocatepec, on which M. Sonnenschmidt, a zealous mineralogist, had the courage to ascend 2557 toises, is higher than the peak of Orizaba, which has hitherto been considered the highest colossus of the country of Anahuac: he measured also the great pyramid of Cholula, a mysterious work constructed of unbaked brick by the Tultequas, and from the summit of which there is a most beautiful view over the snowy summits and smiling plains of Tlaxcala.

After these researches they descended by Perote to $\mathrm{Xa}$ lapa, a town situated at the height of 674 toises above the level of the sea, at a mean height at which the inhabitants enjoy the fruits of all climates, and a temperature equally mild and beneficial to the health of man. It was here that, by the kindness of Mr. Thomas Murphy, a respectable individual, who to a large fortune adds a taste for the sciences, our travellers found every facility imaginable for performing their operations in the neighbouring mountains.

The level of the horrid road which leads from Xalapa to Perote, through almost impenetrable forests of oaks and firs, and which has begun to be converted into a magnificent causeway, was three times taken with the barometer. M. Humboldt, notwithstanding the quantity of snow which 
had fallen the evening before, ascended to the summit of the famous Cofre, which is 162 toises higher than the peak of Teneriffe, and fixed its position by direct observations. He measured also trigonometrically the peak of Orizava, which the Indians call Sitlaltepetl, because the luminous exhalations of its crater resemble at a distance a falling star, and respecting the longitude of which $\mathrm{M}$. Ferrer published very exact operations.

After an interesting residence in these countries, where, under the shade of the liquidambar and amyris, are found growing the epidendrum vanilla and convolvulus jalappa, two productirins equally valuable for exportation, our travellers descended towards the coast of Vera Cruz, situated between hills of shifting sand, the reverberation of which causes a suffocating heat; but happily escaped the yellow fever, which prevailed there at the time.

They proceeded in a Spanish frigate to the Havannah to get the collections and herbals left there in 1800 , and, after a stay of two months, embarked for the United States: but they were exposed to great danger in the channel of the $\mathrm{Ba}$ hamas from a hurricane which lasted seven days.

After a passage of thirty-two clays they arrived at Philadelphia; remained in that city and in Washington two months; and returned to Europe in August 1804 by the way of Bourdeaux with a great number of drawings, thirtyfive boxes of collections, and 6000 species of plants.

\section{An Account of Sutton Spa, near Shrewslury. By Dr. Evans *.}

Sutton Spa is situated within two miles south of Shrewsbury, on the slope of a gentle eminence, and close to a village of the same name, the property of the right honourable lord Berwick. The spring issues from a rocky stratum of ash-coloured clay, or argillaceous schistus, containing (as appears by its effervescence with nitrous acid) a small portion of lime; and, in its present unimproved state, yelds but a scanty stream. In the neighbourhood are several beds of soft limestone and coal, the latter mineral accompanying nearly the whole course of Meole-brook. In the Sutton pits it is mixed with so large a proportion of pyrites, or sulphuret of iron, as to be used only for inferior purposes.

* This is a continuation of Mr. Plymley's Account of the Mineral Pro ductions of Shrophire.-See our last Number, p. 304. 